Article

\title{
Spatial Distribution of Salinity and Sodicity in Arid Climate Following Long Term Brackish Water Drip Irrigated Olive Orchard
}

\author{
John Rohit Katuri ${ }^{1,2}$, Pavel Trifonov ${ }^{1}$ and Gilboa Arye ${ }^{1, *}$ \\ 1 French Associates Institute for Agriculture and Biotechnology of Drylands, Jacob Blaustein Institutes for \\ Desert Research, Ben Gurion University of the Negev, Sede Boqer Campus, Midreshet Ben-Gurion 84990, \\ Israel; john.katuri@gmail.com (J.R.K.); paveltri@post.bgu.ac.il (P.T.) \\ 2 Department of Agronomy, Directorate of Crop Management, Tamil Nadu Agricultural University, \\ Coimbatore, Tamil Nadu 641003, India \\ * Correspondence: aryeg@bgu.ac.il
}

Received: 7 November 2019; Accepted: 28 November 2019; Published: 3 December 2019

\begin{abstract}
The availability of brackish groundwater in the Negev Desert, Israel has motivated the cultivation of various salinity tolerant crops, such as olives trees. The long term suitability of surface drip irrigation (DI) or subsurface drip irrigation (SDI) in arid regions is questionable, due to salinity concerns, in particular, when brackish irrigation water is employed. Nevertheless, DI and SDI have been adopted as the main irrigation methods in olive orchards, located in the Negev Desert. Reports on continued reduction in olive yields and, essentially, olive orchard uprooting are the motivation for this study. Specifically, the main objective is to quantify the spatial distribution of salinity and sodicity in the active root-zone of olive orchards, irrigated with brackish water (electrical conductivity; $\mathrm{EC}=4.4 \mathrm{dS} \mathrm{m}^{-1}$ ) for two decades using DI and subsequently SDI. Sum 246 soil samples, representing $2 \mathrm{~m}^{2}$ area and depths of $60 \mathrm{~cm}$, in line and perpendicular to the drip line, were analyzed for salinity and sodicity quantities. A relatively small leaching-zone was observed below the emitters depth $(20 \mathrm{~cm})$, with EC values similar to the irrigation water. However, high to extreme EC values were observed between nearby emitters, above and below the dripline. Specifically, in line with the dripline, EC values ranged from 10 to $40 \mathrm{dS} \mathrm{m}^{-1}$ and perpendicular to it, from 40 to $120 \mathrm{dS} \mathrm{m}^{-1}$. The spatial distribution of sodicity quantities, namely, the sodium adsorption ratio (SAR, $\left(\mathrm{meq} \mathrm{L}^{-1}\right)^{0.5}$ ) and exchangeable sodium percentage (ESP) resembled the one obtained for the EC. In line with the dripline, from 15 to 30 (meq $\left.\mathrm{L}^{-1}\right)^{0.5}$ and up to $27 \%$, in perpendicular to the drip line from 30 to $60\left(\text { meq } \mathrm{L}^{-1}\right)^{0.5}$ and up to $33 \%$. This study demonstrates the importance of long terms sustainable irrigation regime in arid regions in particular under DI or SDI. Reclamation of these soils with gypsum, for example, is essential. Any alternative practices, such as replacing olive trees and the further introduction of even high salinity tolerant plants (e.g., jojoba) in this region will intensify the salt buildup without leaving any option for soil reclamation in the future.
\end{abstract}

Keywords: arid region; brackish water; sub surface drip irrigation (SDI); salinity; sodicity; olives trees

\section{Introduction}

Salinity and drought are the major abiotic stress factors limiting yield in arid regions [1]. To counteract these limitations, advanced irrigation management practices, such as drip irrigation (DI), were introduced and soon hailed as a breakthrough in agricultural efficiency [2]. Additionally, advanced breeding methods and genetic engineering tools have been developed to confer abiotic stress tolerance in different crops, with emphasis on enhanced tolerance to drought and high soil salinity [3]. With the advent of these technologies, saline water agriculture has gained importance and facilitated cultivation 
in arid environments. Due to drought conditions (low precipitation) in arid regions soil, salinity often increases, impeding plant water uptake. The initial plant responses to salinity and drought stress are fundamentally identical across species and are often complex [4,5]. Plant root adaptations play a key role in coping with these stresses [6]. For the successful management of arid agriculture choice of crop, cultivar and irrigation management regimes play a key role.

In the late 1970s, the introduction and cultivation of various saline tolerant crops with brackish water started in the Negev Desert of Israel [7]. Today farmers in the Negev region grow olives using DI or sub-surface drip irrigation (SDI) with brackish ground water (EC $\sim 4.5 \mathrm{dS} \mathrm{m}^{-1}$ ) from the local aquifer, as they have no alternative for other economical irrigation water source [8]. Olive trees are generally tolerant of drought and salinity $[9,10]$. However, salinity tolerance in olives is a cultivar specific trait. The main active root zone distribution in olives trees is at a depth of 30 to $60 \mathrm{~cm}[11,12]$ and various studies have reported that the upper critical limit of soil EC for normal olive development is 4 to $6 \mathrm{dS} \mathrm{m}^{-1}$ [12-15]. In olives trees, the maximum root growth rate can be achieved under fresh water irrigation and the high root mortality rate and root growth restriction occurs under moderately saline irrigation (4.2 $\left.\mathrm{dS} \mathrm{m}^{-1}\right)$ [16-19]. Irrigation water salinity of $4 \mathrm{dS} \mathrm{m}^{-1}$ limits significant production of the potential yield possible with good quality water [15] and there is a gradual buildup of soil salinity over the years in the root zone [16]. Therefore, an appropriate management of irrigation regime and salinity in root zone is necessary to optimize yield and oil quality in olive orchards irrigated with saline water $[15,20]$.

In the long term, the commitment to utilizing marginal irrigation water sources, such as brackish water, may be fundamentally unsustainable, in particular, in arid lands where precipitation is too low to leach the accumulated salts from the active root zone [21]. There is a higher risk of soil salinization if rainfall is lower than $250 \mathrm{~mm}$ and the salts are not leached from the upper $60 \mathrm{~cm}$ depth [22-24]. The Negev region has an arid climate with high rates of evapotranspiration (about $2600 \mathrm{~mm} \mathrm{year}^{-1}$ ) and low rainfall (70 to $125 \mathrm{~mm} /$ year) [8,25]. When SDI was employed it reduced evaporation and improved irrigation water-use efficiency with olive yield similar to DI irrigation [26,27]. However, in SDI systems, salt accumulation above the dripper is high and does not offer an advantage over DI in regard to soil salt distribution under conditions of high evaporative demand $[28,29]$. In arid and semiarid areas, using SDI placed at shallow depths (about $20 \mathrm{~cm}$ ) resulted in large amounts of salt accumulation near the soil surface [30], specifically located above the dripline [31,32]. When salts accumulate in soil surface layers, sprinkler irrigation is commonly used in SDI plots to leach salts below the drip tapes, but, in the long term it affects the economic sustainability of SDI [30]. Nevertheless, it was recently demonstrated $[33,34]$ that a sequential practice of sprinkler irrigation for potato germination, followed by low discharge shallow SDI with brackish irrigation water, can result in similar potato yields to traditional methods that utilize sprinkler irrigation with fresh water.

There is high transient salinity and sodicity risk associated with saline water SDI in orchards [35] and they change with the amount and quality of infiltrated water, evapotranspiration rates, and rainfall [36]. When water quality of EC $>2.5 \mathrm{dS} \mathrm{m}^{-1}$ and SAR $>4$ was used in olive and other orchards with SDI, there was a significant increase in soil salinity and sodicity values at 0-60 $\mathrm{cm}$ soil depths [37-40]. Most studies which examined the salinity and/or sodicity effect on olive growth and yield are short term $(<8$ years) studies $[19,24,41,42]$ and, consequently, a severe accumulation of salts in the soil profile was not reported.

As mentioned, the introduction and cultivation of salt-tolerant crops in the arid regions in conjunction with brackish irrigation water for the past few decades has resulted in increasing soil salinity. In the current study, we quantify the salinity and sodicity spatial distribution in an olive orchard following twenty years of irrigation with brackish water. The motivation for this study stems from recent reports on continues decrease in yields (Figure 1) and the eventual uprooting of some olive orchards due to unprofitability. Therefore, it is necessary to understand the sustainability of olive cultivation under saline brackish water with SDI, so that secondary salinization is prevented and the soil can be reclaimed for agriculture in future years. The main objective of this study is to fill the 
knowledge gap regarding the spatial distribution of salinity and sodicity in long term sub-surface drip irrigated soils with brackish irrigation water. Given the relatively high distance $(1 \mathrm{~m})$ between drippers, we hypothesized that a high level of salinity and sodicity will be established between nearby drippers.

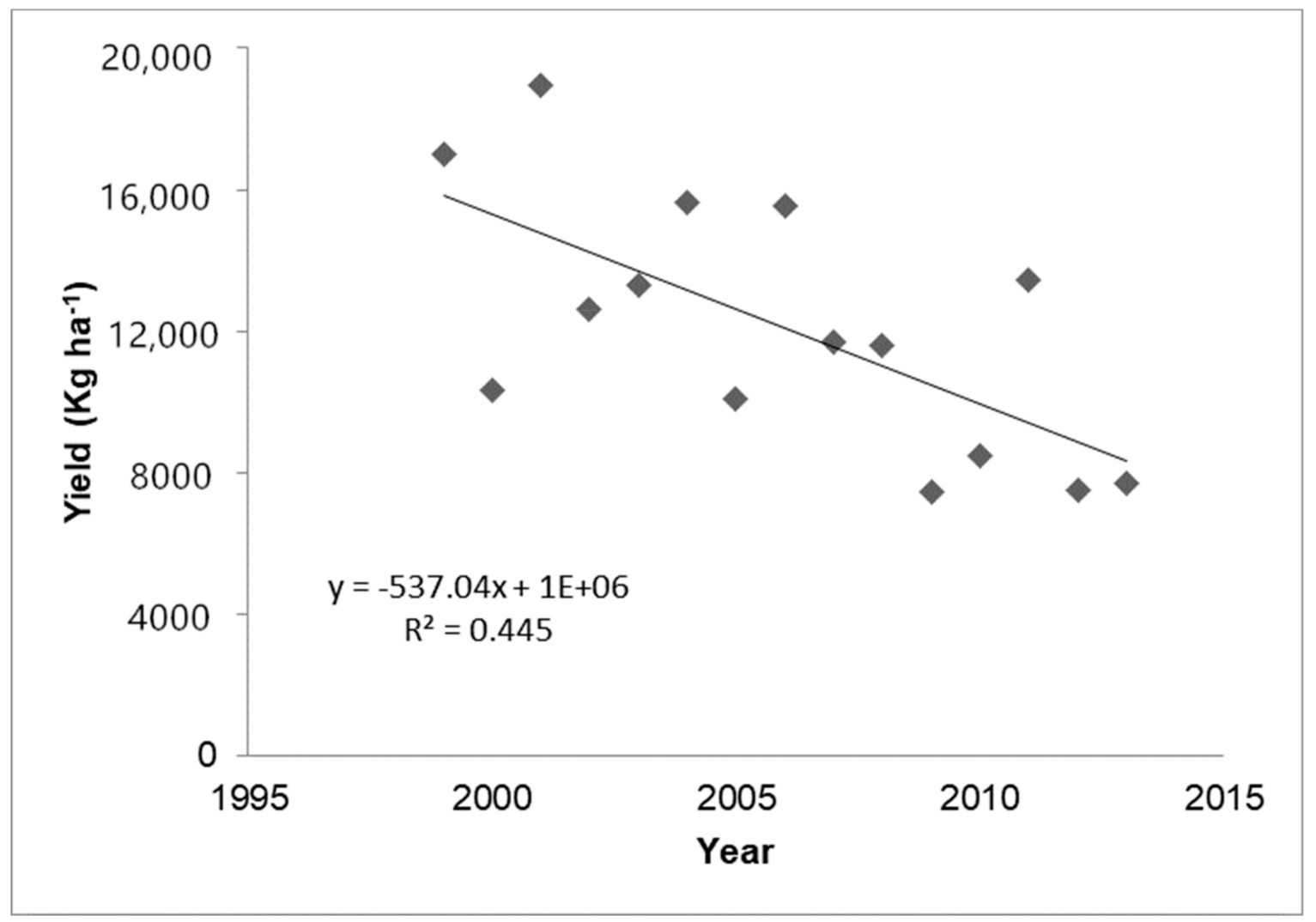

Figure 1. Yield trend for 15 years of the Barnea olive variety grown in the Revivim orchard.

\section{Materials and Methods}

\subsection{Site Description}

A field investigation was carried out in the olive (Olea europaea) cultivar 'Barnea' orchard of Kibbutz Revivim (31.0436 ${ }^{\circ}$, 34.7212 ${ }^{\circ}$ E), located in the central Negev Desert, Israel. The climatic conditions of the location are of the typical arid type, with cooler night temperatures and hot, dry summers (Figure 2). The mean annual rainfall ranges from 75 to $125 \mathrm{~mm}$ [25]. During the 2014/2015 season, the total precipitation was $105 \mathrm{~mm}$ and cumulative potential evapotranspiration was $2500 \mathrm{~mm}$ (Figure 3). The olive orchard was planted in 1995 and has been irrigated with brackish groundwater $\left(E C=4.4 \mathrm{dS} \mathrm{m}^{-1}\right)$ since then, for approximately 20 years. Water quality parameters of the brackish irrigation water are presented in Table 1.

During the first 15 years, DI was used but later converted to SDI by placing drip laterals at $20 \mathrm{~cm}$ soil depth and about $1 \mathrm{~m}$ distance from the tree line with an emitter flow-rate of $4 \mathrm{~L} \mathrm{~h}^{-1}$ and $1 \mathrm{~m}$ distance between nearby emitters. An initial tree spacing of about $3 \times 7 \mathrm{~m}$ was first established and after ten years, each alternate tree within a row was uprooted, giving the current spacing of $6 \times 7 \mathrm{~m}$. Irrigation was scheduled according to class evaporation pan located nearby the orchard. Specifically, in average, a factor of $35 \%$ to $60 \%$ was used to calculate the irrigation amounts from the predetermined cumulative pan evaporation (class A pan) [8]. Accordantly, irrigation intervals were scheduled every 3 days during summer and every 7 days during winter. Approximately, $800 \mathrm{~mm}$ plus an excess of $100 \mathrm{~mm}$, as the leaching requirement of irrigation water, was applied annually. 


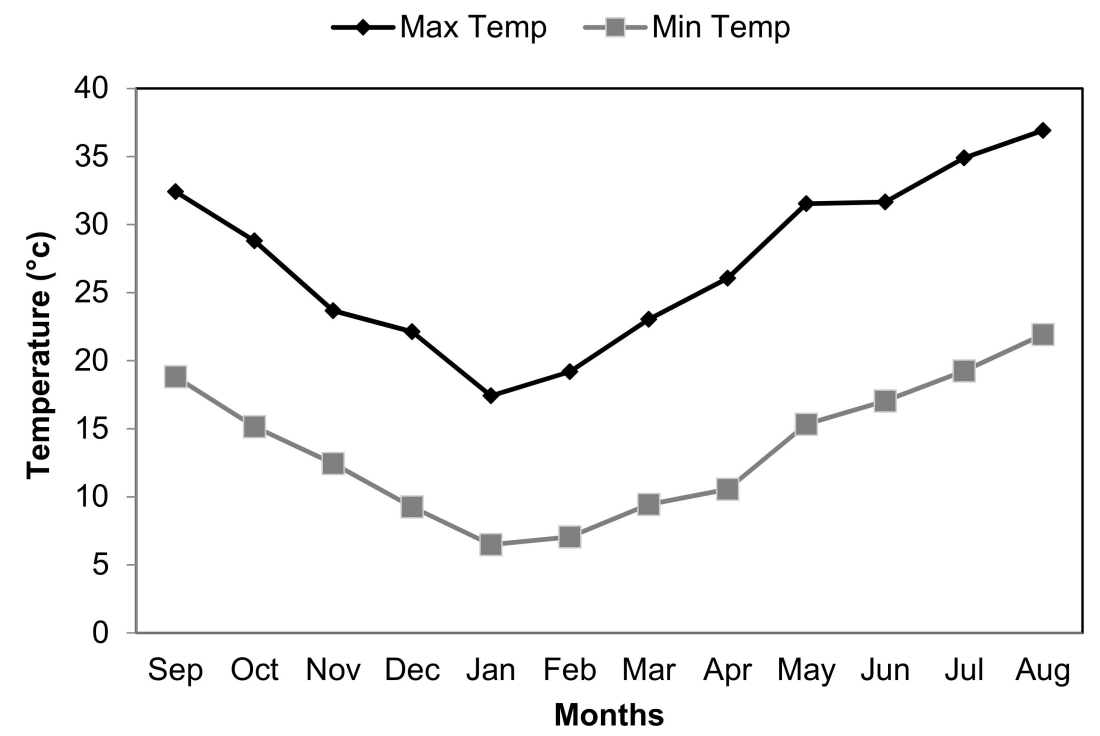

Figure 2. Minimum and maximum temperature in Revivim during 2014-2015.

- ETo 2014-15 —Rainfall 2014-15

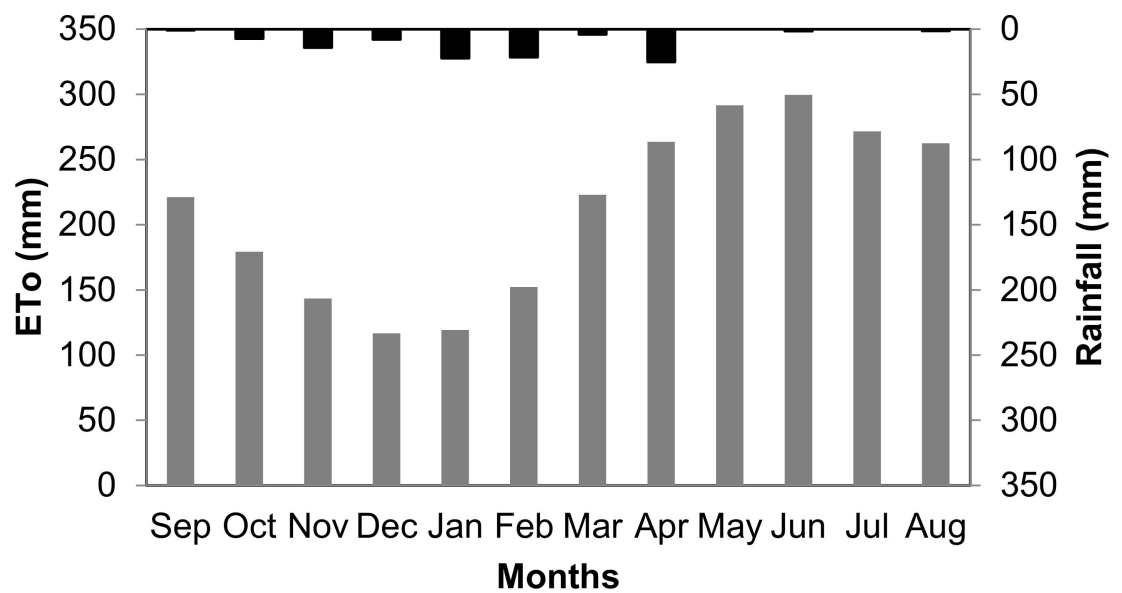

Figure 3. Rainfall and potential evapotranspiration (ETo) in Revivim during 2014-2015.

Table 1. Irrigation water quality parameters (Mekerot Water Company).

\begin{tabular}{cl}
\hline Parameter & Value \\
\hline Boron $\left(\mathrm{mg} \mathrm{L}^{-1}\right)$ & 1.200 \\
Calcium $\left(\mathrm{mg} \mathrm{L}^{-1}\right)$ & 171.000 \\
Chloride $\left(\mathrm{mg} \mathrm{L}^{-1}\right)$ & 1120.000 \\
Electrical Conductivity dS m & -1 \\
$\mathrm{CaCO}_{3}\left(\mathrm{mg} \mathrm{L}^{-1}\right)$ & 4.400 \\
$\mathrm{HCO}_{3}\left(\mathrm{mg} \mathrm{L}^{-1}\right)$ & 748 \\
Potassium $\left(\mathrm{mg} \mathrm{L}^{-1}\right)$ & 301 \\
Magnesium $\left(\mathrm{mg} \mathrm{L}^{-1}\right)$ & 1900 \\
Sodium $\left(\mathrm{mg} \mathrm{L}^{-1}\right)$ & 78.000 \\
$\mathrm{pH}$ & 684.000 \\
Total organic carbon $\left(\mathrm{mg} \mathrm{L}^{-1}\right)$ & 7.000 \\
Total dissolved matter $\left(\mathrm{mg} \mathrm{L}^{-1}\right)$ & $<0.200$ \\
SAR (meq L & 2697.000 \\
\hline
\end{tabular}




\subsection{Soil Sampling and Analysis}

Comprehensive soil sampling was carried out to explore the spatial distribution of salinity and sodicity along and perpendicular to the drip-line, representing a total area of $2 \mathrm{~m}^{2}$ (Figure 4). Soil samples were collected from 41 locations along the drip-line between three nearby emitters that were perpendicular and diagonal to the central emitter. At each sampling location, disturbed soil samples ( $\mathrm{n}=246$ ) were taken from six depths: $0-5,5-10,10-15,15-30,30-45$, and $45-60 \mathrm{~cm}$. In addition, representative intake soil samples were taken near the sampling locations mentioned above, from which the bulk density of each layer was calculated (Table 2). The gravimetric water content (WC) was measured shortly after the sampling event from the differences in weight before and after drying at $105^{\circ} \mathrm{C}$ for $24 \mathrm{~h}$. The rest of the soil samples were air-dried and thereafter passed through a 2-mm sieve.

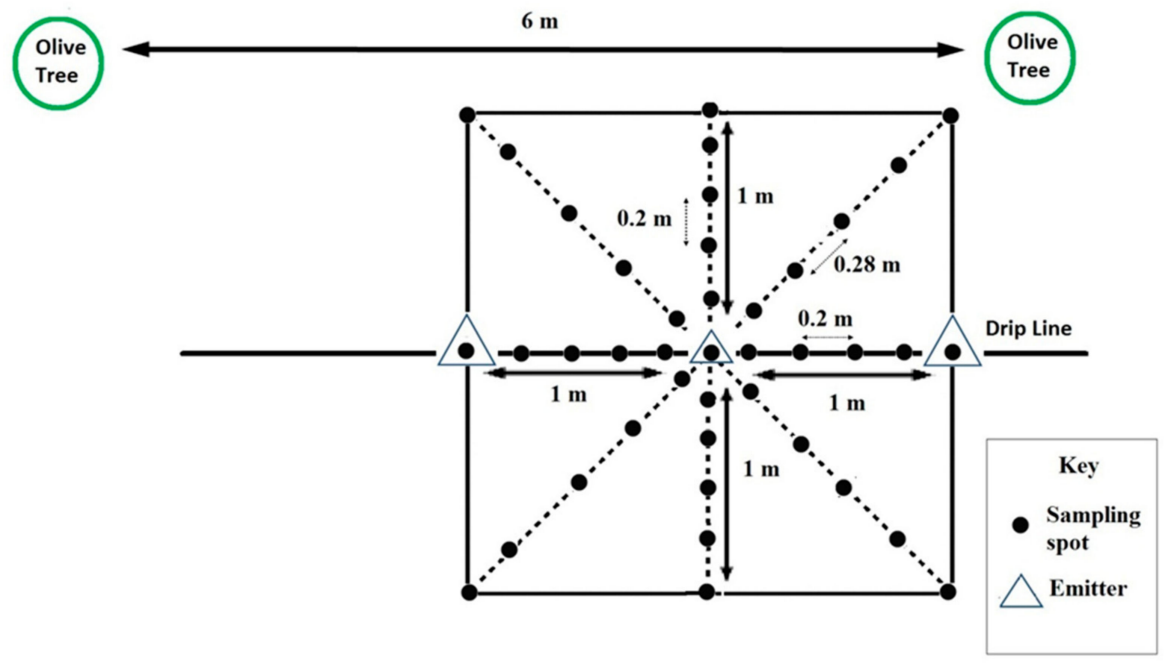

Figure 4. Schematic view of soil sampling spots in an olive orchard under sub surface drip irrigation.

Table 2. Revivim olive orchard soil properties.

\begin{tabular}{cccccccccc}
\hline \multirow{2}{*}{ Depth } & \multirow{2}{*}{ Texture } & Sand & Silt & Clay & $\begin{array}{c}\text { Organic } \\
\text { Matter }\end{array}$ & $\begin{array}{c}\text { Bulk } \\
\text { Density }\end{array}$ & CEC & SSA $^{*}$ & CaCO $_{3}$ \\
\hline (cm) & & $(\%)$ & $(\%)$ & $(\%)$ & $(\%)$ & $\left(\mathrm{g} / \mathrm{cm}^{3}\right)$ & $(\mathrm{meq} / 100 \mathrm{~g})$ & $\left(\mathrm{g} / \mathrm{m}^{2}\right)$ & $(\%)$ \\
\hline \multirow{2}{*}{$0-5$} & \multirow{2}{*}{ Loamy Sand } & $80.83 \pm$ & $11.67 \pm$ & 7.50 & $10.22 \pm$ & $0.96 \pm$ & $8.54 \pm$ & 28.29 & $8.0 \pm 3.5$ \\
& & 5.77 & 5.77 & 0.00 & 0.05 & 0.017 & 1.13 & 0.00 & \\
\multirow{2}{*}{$5-10$} & \multirow{2}{*}{ Sandy Loam } & $70.83 \pm$ & $16.67 \pm$ & $12.50 \pm$ & $5.41 \pm$ & $1.09 \pm$ & $9.27 \pm$ & $57.19 \pm$ & $8.9 \pm 1.5$ \\
& & 1.44 & 2.89 & 2.5 & 3.28 & 0.006 & 0.77 & 14.45 & \\
$10-15$ & \multirow{2}{*}{ Sandy Loam } & 67.50 & $19.17 \pm$ & $13.33 \pm$ & $1.62 \pm$ & $1.46 \pm$ & $8.61 \pm$ & $62.00 \pm$ & $8.5 \pm 2.3$ \\
& & 0.00 & 2.89 & 2.89 & 0.17 & 0.006 & 0.22 & 16.69 & \\
$15-30$ & \multirow{2}{*}{ Sandy Loam } & $65.83 \pm$ & $19.17 \pm$ & 15.00 & $1.60 \pm$ & $1.48 \pm$ & $8.59 \pm$ & 71.64 & $9.5 \pm 1.6$ \\
& & 5.20 & 5.20 & 0.00 & 0.20 & 0.006 & 0.63 & 0.00 & \\
$30-45$ & \multirow{2}{*}{ Loam } & $50.83 \pm$ & $28.33 \pm$ & $20.83 \pm$ & $1.53 \pm$ & $1.45 \pm$ & $9.19 \pm$ & $105.35 \pm$ & $8.6 \pm 1.2$ \\
& & 3.82 & 1.44 & 2.89 & 0.21 & 0.006 & 0.94 & 16.69 & \\
$45-60$ & \multirow{2}{*}{ Loam } & $54.17 \pm$ & $27.50 \pm$ & $18.33 \pm$ & $1.38 \pm$ & $1.47 \pm$ & $9.03 \pm$ & $90.90 \pm$ & $10.9 \pm$ \\
& & 3.82 & 2.50 & 1.44 & 0.11 & 0.006 & 0.19 & 8.34 & 1.9 \\
\hline
\end{tabular}

\pm Standard deviation, SSA — specific surface area (calculated according to [43]).

The concentration of the main cations $(\mathrm{Na}, \mathrm{K}, \mathrm{Mg}$, and $\mathrm{Ca}$ ) in the soil solution was obtained from the extraction of the soil to distilled water ratio of 1:1. Samples were shaken on an end-over shaker and then centrifuged at $4000 \mathrm{rpm}$ for $10 \mathrm{~min}$. The supernatant was analyzed for soluble cations, bicarbonate, and chloride concentration. The cation exchange capacity (CEC) was measured by the sodium acetate method [44] and the exchangeable cations concentrations ( $\mathrm{xNa}, \mathrm{xK}, \mathrm{xMg}$, and $\mathrm{xCa})$ from the sodium acetate extraction [45]. The cations concentration was measured by atomic adsorption spectrophotometer (Analyst 400, ParkinElmer) and Chloride $\left(\mathrm{Cl}^{-1}\right)$ concentration by Chloride Analyzer (926, Sherwood). 
The sodium adsorption ratio (SAR) and the exchangeable sodium ratio (ESR) were calculated according to the Gapon equation.

$$
\frac{x N a}{x C a+x M g}=K_{G} \cdot \frac{N a}{\sqrt{0.5 \cdot(C a+M g)}} \equiv E S R=K_{G} \cdot S A R
$$

where, the concentrations of the soluble and exchangeable cation are in meq $\mathrm{L}^{-1}$ and meq $\mathrm{Kg}^{-1}$, respectively. The $K_{G}$ is the Gapon selectivity coefficient.

Contours map of the spatial distribution of the WC, EC, $\mathrm{Cl}^{-1}, \mathrm{SAR}$, and ESP in the soil profile were established with Surfer software (version 8, Golden Software, Colorado, USA) using the Kriging regression.

\section{Results and Discussion}

From the soil properties (Table 2) it can be seen that the texture in the examined soil layers changes from loamy-sand in the top soil layer $(0-5 \mathrm{~cm})$, sandy-loam in the middle ones $(5-30 \mathrm{~cm})$, and loam in the deeper layers $(30-60 \mathrm{~cm})$. A distinct difference in organic matter $(\mathrm{OM})$ percentage could be observed from $10.2 \%(0-5 \mathrm{~cm}), 5.4 \%(5-10 \mathrm{~cm})$ and similar values ranging from $1.62 \%$ $(10-15 \mathrm{~cm})$ to $1.38 \%(45-60 \mathrm{~cm})$. The bulk density exhibited an inverse linear correlation to OM content $\left(\mathrm{BD}=1.54-0.06 \times \mathrm{OM}, \mathrm{R}^{2}=0.93\right)$ rather than any of size fractions; ranging from about $1 \mathrm{~g} \mathrm{~cm}^{-3}$ in the top soil layer $(0-10 \mathrm{~cm})$ and exhibited similar values of about $1.45 \mathrm{~g} \mathrm{~cm}^{-3}$ for the rest of the soil profile. The above observation may imply a higher water holding capacity in the top soil layers, due to water adsorption and/or structures formation induced by the level of soil OM.

In the followings, the spatial distribution obtained for water content, salinity, and sodicity quantities are presented for two $60 \mathrm{~cm}$ soil transect: (i) along the drip line and (ii) perpendicular to the drip line (crossing the middle dripper), (Figure 4). In addition, a three dimensional visualization is presented as a counter map calculated from all measured data points of the four transects for a given soil layer (Table 2).

\subsection{Water Content Spatial Distribution}

In Figure 5 the spatial distribution obtained for the WC is presented for the sampled transect along (Figure 5a) and perpendicular (Figure $5 b$ ) to the drip line. The WC distribution demonstrates that relatively higher WC can be found directly above and below the location of the emitters (i.e., $20 \mathrm{~cm}$ depth). A typical wetting bulb of relatively light-texture soil can be observed with the bulb radius; the horizontally wetted radius is less than the vertically wetted depth radius $[46,47]$. The near-saturation zone was located about $20 \mathrm{~cm}$ from the emitters from which a gradual reduction in WC can be observed up to $50 \mathrm{~cm}$ distance, which is located in the middle, between two nearby drippers. At this location, the WC above the emitters is the lowest one, suggesting that there is no significant overlap between nearby emitters. The relatively large distance between the emitters (i.e., $1 \mathrm{~m}$ ) and the corresponding spatial distribution of the WC also affected the salinity and sodicity spatial distribution, as is demonstrated below. Regarding the perpendicular transect (Figure 5b), it should be noted that $+100 \mathrm{~cm}$ on the $x$-axis is towards the tree-line and $-100 \mathrm{~cm}$ is towards the road, i.e. away from the tree-line. Toward the tree-line, there is a gradual reduction in WC which is likely due to root water uptake. Away from the tree-line, the reduction in WC may stem from higher evaporation rates, due to less shading from the tree.

The three dimensional visualization (Figure 6) shows an entire $2 \mathrm{~m}^{2}$ view for the spatial WC distribution at six individual depths (Table 2). It is clearly illustrated that down to $30 \mathrm{~cm}$ (the three top layers), the dryer zone prevails toward the tree line compared to the corresponding locations, away from the tree line. The dryer WC zone may indicate water uptake by the active root zone [11,12]. The relatively low overlap between the wetting fronts of the nearby emitters is also illustrated, suggesting that in the long-term, the solute fluxes, due to convection, dispersion, and diffusion might have reached the wetting front of individual emitter and accumulated at this location. Consequently, in the long-term, higher salinity can be expected between emitters and perpendicular to the emitter. 


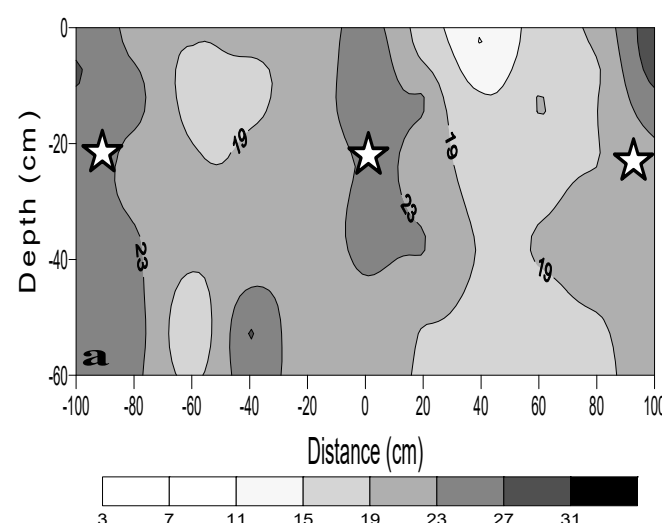

(a)

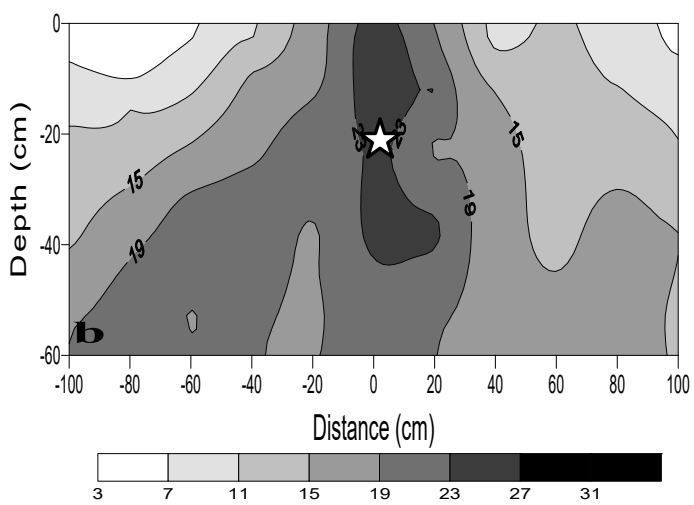

(b)

Figure 5. Gravimetric water content (\%) distribution (a) along the drip line and (b) perpendicular to the drip line. The black and white stars indicate the location of the drippers.

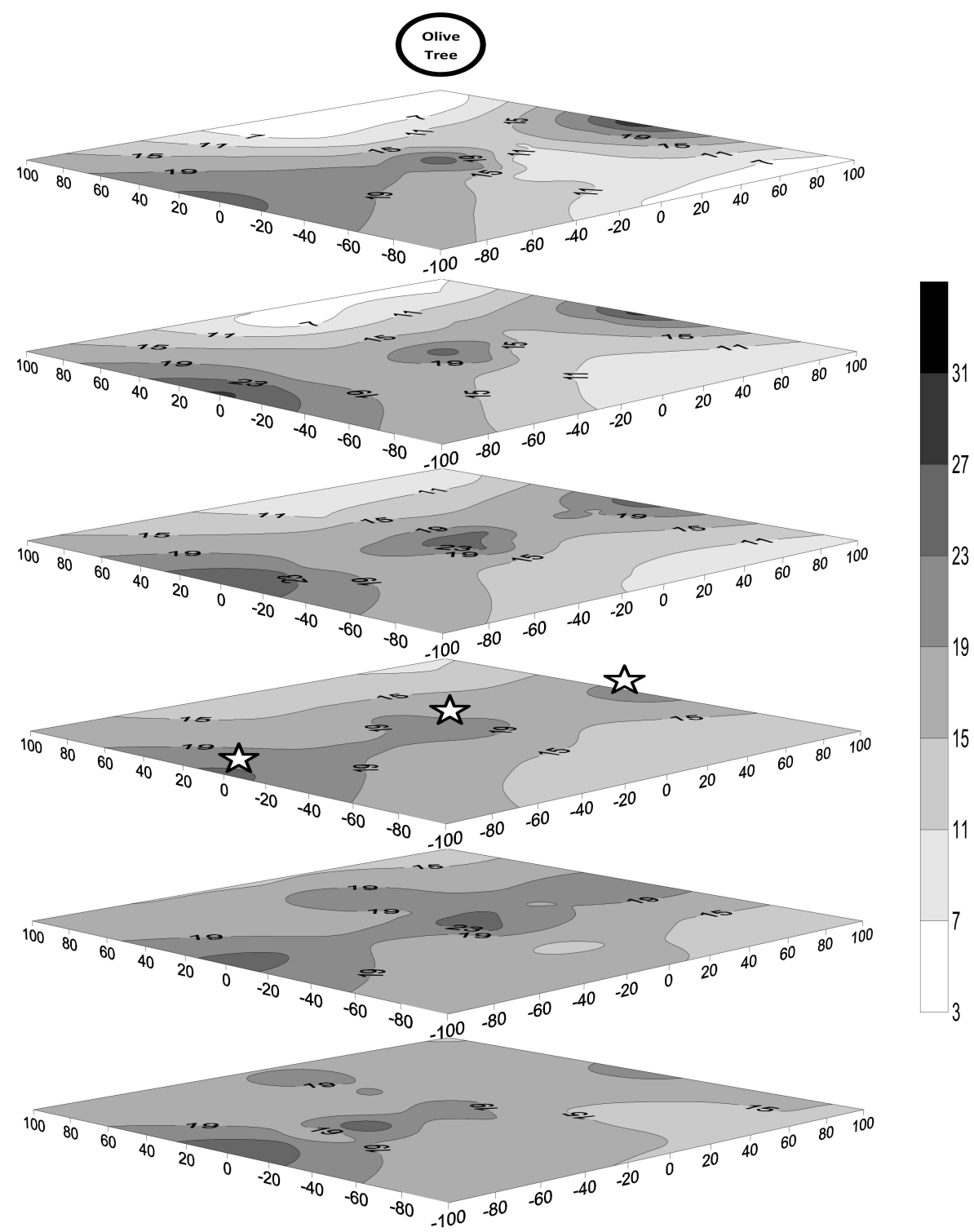

Figure 6. An overall gravimetric water content (\%) distribution at all six depths, $0-5,5-10,10-15,15-30$, $30-45$, and $45-60 \mathrm{~cm}$. The black and white stars indicate the location of the drippers. 


\subsection{Salinity Spatial Distribution}

Two quantities were used to describe the long-term accumulation of salinity: (i) electrical conductivity (EC) — representing the total salinity, and (ii) chloride concentration-as a soil native conservative tracer. The EC distribution is shown for the transect along (Figure 7a) and perpendicular (Figure $7 \mathrm{~b}$ ) to the drip line. The chloride distribution is shown in Figure $7 \mathrm{c}$ and $\mathrm{d}$ for transects along and perpendicular to the drip line, respectively. For both transects, salinity and chloride distribution exhibited similar patterns. Specifically, both quantities demonstrated a leaching zone above and below the emitters and salt accumulations zone between nearby emitters. For the transect along the drip-line, the highest salinity prevailed above the drip line in the middle of two nearby emitters. Nevertheless, the salinity values below the drip-line are also very high and may reduce water uptake by the olive trees' roots, due to the high osmotic pressure, even if a high water content is maintained. Regarding the perpendicular transect, a distinct, uneven distribution could be observed. Specifically, the salt accumulation away from the tree $(-100$ to $0 \mathrm{~cm})$ is significantly higher than the one obtained toward the tree line $(0$ to $100 \mathrm{~cm})$. The lowest salinity obtained near the tree line may be explained by a reduced evaporation and capillary rise toward the soil surface, due to the surface shading by the olive trees. However, the entire zone exhibited very-high to extreme values of EC, which indicates the salinization of the olive plantation, as clearly illustrated from the three dimensional visualization of the entire $2 \mathrm{~m}^{2}$ view of the spatial EC distribution at six individual depths (Figure 8). The representation of the entire domain emphasizes the extreme values of salinity above the drip-line and away from the tree-line. A clear pattern could not be observed, due to the large salinity spectrum that was considered in this counter map. Nevertheless, the leaching zones above and below the emitter is clearly demonstrated, indicating moderate to high salinity levels.
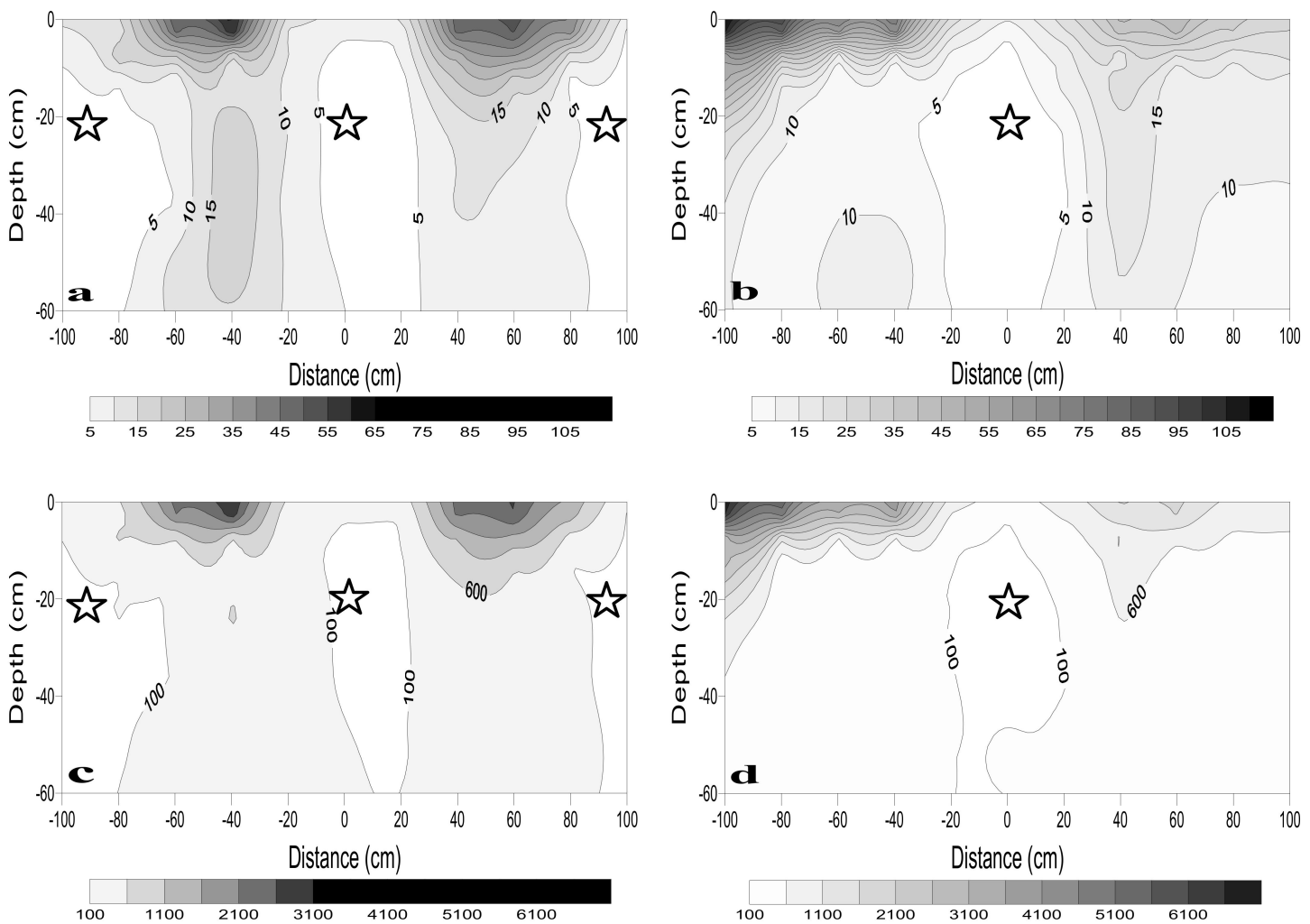

Figure 7. Electrical conductivity $\left(\mathrm{dS} \mathrm{m}^{-1}\right)$ distribution (a) along the drip line, (b) perpendicular to the drip line, and soil chloride $\left(\mathrm{mg} \mathrm{L}^{-1}\right)$ distribution (c) along the drip line and (d) perpendicular to the drip line. The black and white stars indicate the location of the drippers. 


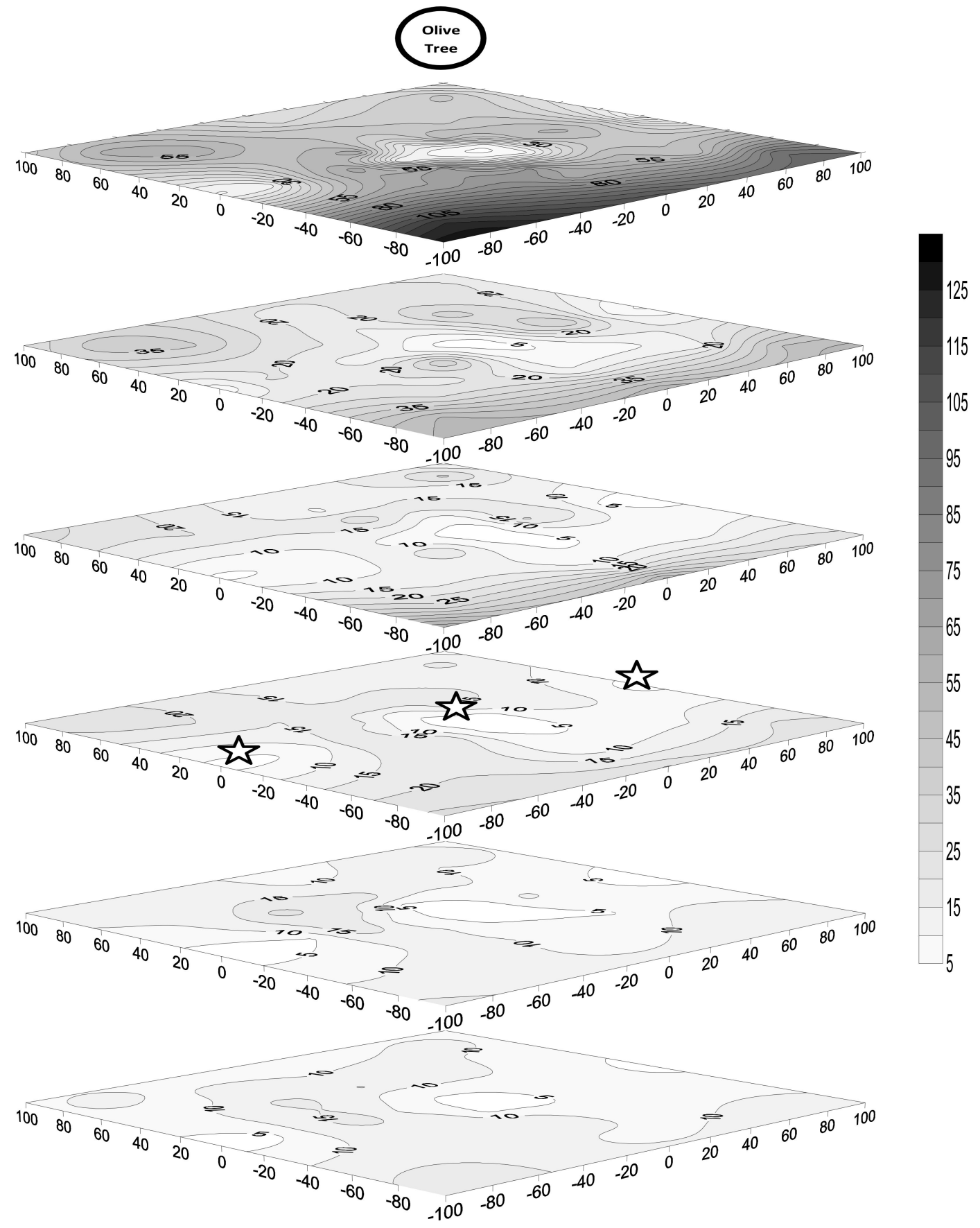

Figure 8. An overall distribution of the electrical conductivity $\left(\mathrm{dS} \mathrm{m} \mathrm{m}^{-1}\right)$ at all six depths, 0-5, 5-10, $10-15,15-30,30-45$, and $45-60 \mathrm{~cm}$. The black and white stars indicate the location of the drippers.

As mentioned, the mean annual rainfall in this region is below $125 \mathrm{~mm}$ and may be distributed over ten low-rain events (Figure 3). Under these conditions, there is insufficient rain to leach the accumulated salts from the soil surface below the active root zone. This minimal rainfall can also exacerbate the salinity problem by bringing surface salts $(0-15 \mathrm{~cm})$ to the root zone $(30-60 \mathrm{~cm})$ after one or several rainfall events. The salinity observed in the orchard soils is far above the normal threshold salinity level for olive growth, i.e., a soil EC value of 4 to $6 \mathrm{dS} \mathrm{m}^{-1}$ is the accepted critical limit for normal olive growth [12-15]. To leach the excess salts from the root zone, high rainfall events $>600 \mathrm{~mm}$ are required $[48,49]$ or sprinkler irrigation has to be implemented in order to leach salts, but the long-term economic sustainability of this system is questionable [30]. 


\subsection{Sodicity Spatial Distribution}

The outcome of the long-term sodification is described by the calculated values of the SAR as a measure for the sodicity of the liquid phase and by the sodium adsorption percentage $(\mathrm{ESP}=100 \mathrm{xNa} / \mathrm{CEC})$ as a measure the sodicity of the solid phase. The spatial SAR distribution is shown for the transect along (Figure 9a) and perpendicular (Figure 9b) to the drip line. The spatial ESP distribution is shown in Figure $9 \mathrm{c}, \mathrm{d}$ for transects along and perpendicular to the drip line, respectively. In general terms, the spatial distribution patterns obtained for the SAR and ESP resemble the one obtained for the salinity (Figure 7), demonstrating that a higher salinity in the soil solution resulted in higher SAR and consequently higher ESP. The SAR values obtained between nearby emitters, above a below the dripline, exhibited values $>15 \%$ and reached values even higher than $30 \%$ at the top soil layers (Figure 10). Therefore, sodicity hazardous of soil structure degradation which can negatively affects soil hydraulic properties should be considered. Nevertheless, since high sodicity levels were accompanied by high salinity levels, the latter, may offset the negative sodicity effect on the stability of soil structure. The fact that sodicity levels increased with salinity implied a chemical equilibrium between the soil-solution and solid phase. In support of this argument is the linear correlation obtained from all samples between the ESR and SAR (Figure 11) with a slope of 0.0134 , which is close to the commonly accepted value of the Gapon constant, $\mathrm{K}_{\mathrm{G}}=0.015$, e.g., [50]. In addition, a positive linear correlation was obtained (data is not shown) between ESP and SAR (ESP $=0.77 S A R+3.34, R^{2}=0.73$ ). It is well established [51] that if cation exchange reactions have reached equilibrium, the ESP values are similar to the SAR at the range of 0 to 40 .
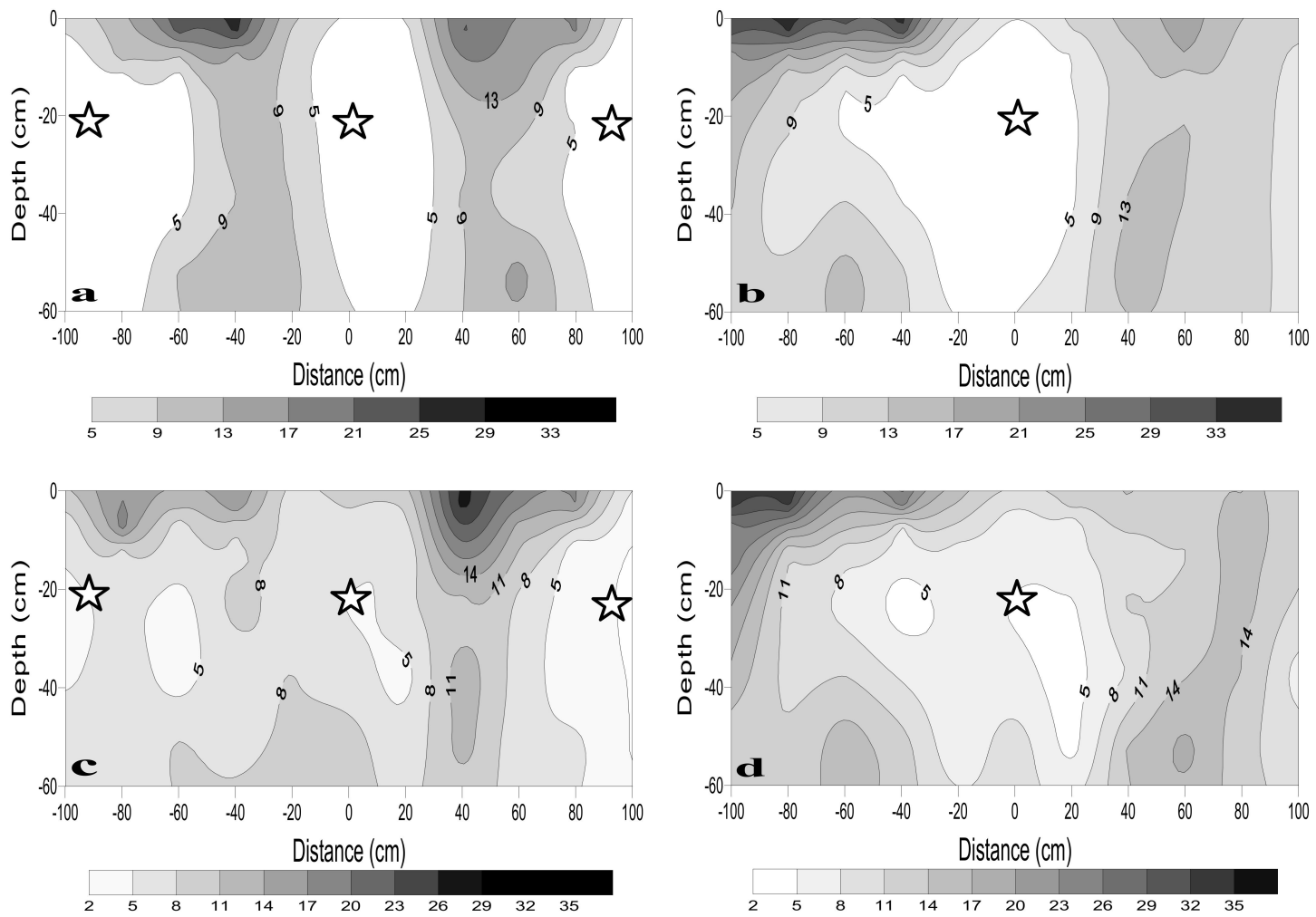

Figure 9. SAR (meq L $\left.{ }^{-1}\right)^{0.5}$ distribution (a) along the drip line, (b) perpendicular to the drip line and, ESP (\%) distribution, (c) along the drip line, and (d) perpendicular to the drip line. The black and white stars indicate the location of the drippers. 


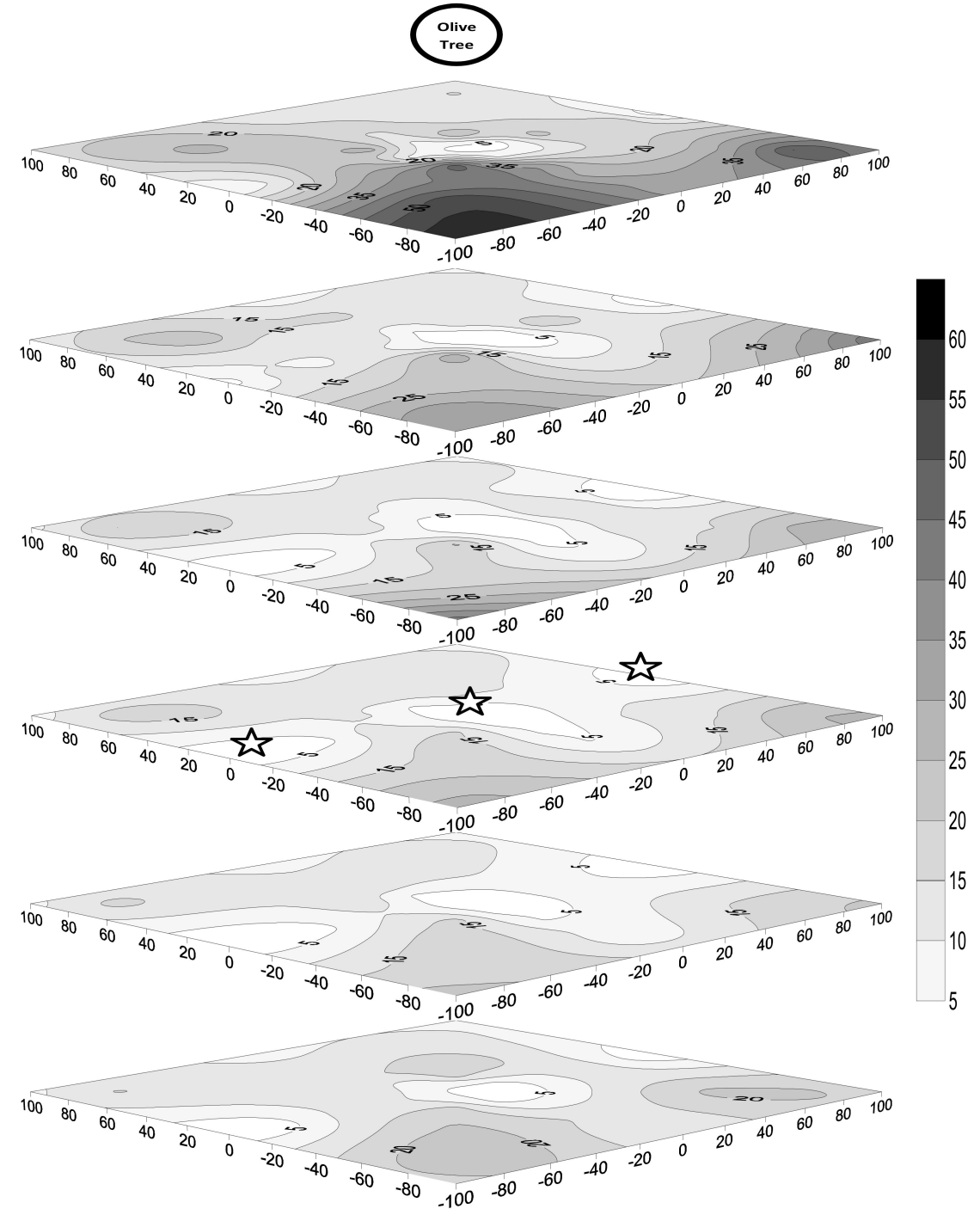

Figure 10. An overall distribution of the SAR (meq $\left.\mathrm{L}^{-1}\right)^{0.5}$ at all six depths, $0-5,5-10,10-15,15-30$, $30-45$, and $45-60 \mathrm{~cm}$. The black and white stars indicate the location of the drippers.

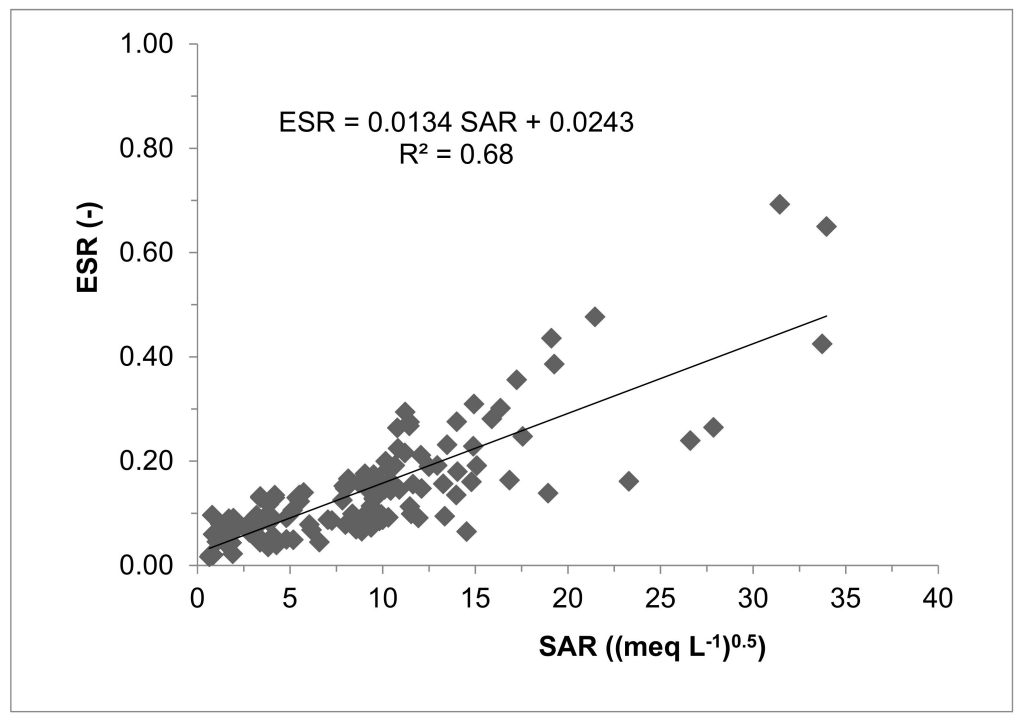

Figure 11. Exchangeable sodium ratio (ESR) as a function of sodium adsorption ratio (SAR). 


\section{Summary and Conclusions}

The main goal of this study was to quantify the long term development of salinity and sodicity in an olive orchard grown in an arid region and irrigated with brackish water for two decades using DI and, subsequently, SDI. The study was motivated by reports on olive orchard uprooting in the Negev Desert, due to the continual reduction in olive yields. We assumed that under the climate conditions that prevail in this arid region, long term salinization and sodification at the active root zone is inevitable, in particular, under SDI with brackish irrigation water. The results of this study clearly demonstrate that following twenty years of irrigation with brackish irrigation water, salinization and sodification took place in the examined soil profile $(0-60 \mathrm{~cm})$, which represents the active root zone of the olive trees. The relatively large distance $(1 \mathrm{~m})$ between nearby drippers resulted in no significant overlaps between the wetting fronts of two nearby emitters. Consequently, a relatively small area of salt leaching could be observed below the emitters, with EC values close to the ones in the brackish irrigation water. However, moderate salt buildup took place above the emitters. The salinity buildup between nearby emitters were above the salinity threshold level for olive trees with extreme EC values above the drip line and high ones below it. The spatial distribution of the sodicity levels resembled the ones obtained for salinity, corresponding to high sodicity levels (in terms of SAR and ESP) where salinization took place. The linear correlation obtained between the sodicity quantities (i.e., ESR vs. SAR and ESP vs. SAR) implies that chemical equilibrium has been reached between the brackish irrigation water, soil solution, and the solid phase.

The results of this study show that in arid regions, the benefits of water saving, attributed to SDI, are masked by soil salinization and sodification that was induced by this irrigation method. The quantification of the long term suitability of brackish water irrigation with SDI may assist in improving the irrigation system design, for example, by significantly reducing the distance of nearby emitters and increasing the allocated leaching fraction. Finally, this study emphasizes the current necessity for salinity and sodicity reclamation in the studied region. Any alternative practices of replacing olives trees and further introduction of even higher salinity tolerant plants (e.g., jojoba) in this region will intensify the salt buildup without leaving any option for soil reclamation in the future.

Author Contributions: The study was conceived and designed by G.A., J.R.K. and P.T. performed the field experiment. All authors took a part in the data analysis, interpretation, and writing the paper. All authors have read and approved the final manuscript.

Funding: The study was partially funded by the Goldinger Trust, Jewish Federation of Delaware and the Frances and Elias Margolin Trust.

Acknowledgments: We thank E.N. and his team from Kibbutz Revivim for providing the agricultural facilities. We also appreciate the technical assistance and support by Y.M.

Conflicts of Interest: The authors declare no conflict of interest.

\section{References}

1. Ladeiro, B. Saline agriculture in the 21st century: Using salt contaminated resources to cope food requirements. J. Bot. 2012, 2012, 310705. [CrossRef]

2. Siegel, S.M. Let There be Water: Israel's Solution for a Water-Starved World; Macmillan: New York, NY, USA, 2015.

3. Fita, A.; Rodríguez-Burruezo, A.; Boscaiu, M.; Prohens, J.; Vicente, O. Breeding and domesticating crops adapted to drought and salinity: A new paradigm for increasing food production. Front. Plant Sci. 2015, 6, 978. [CrossRef] [PubMed]

4. De Oliveira, A.B.; Alencar, N.L.M.; Gomes-Filho, E. Comparison between the water and salt stress effects on plant growth and development. In Responses of Organisms to Water Stress; Akinci, S., Ed.; IntechOpen: London, UK, 2013.

5. Uddin, M.N.; Hossain, M.A.; Burritt, D.J. Salinity and drought stress: Similarities and differences in oxidative responses and cellular redox regulation. Water Stress Crop Plants Sustain. Approach 2016, 1, 86-101.

6. Muscolo, A.; Sidari, M.; Panuccio, M.R.; Santonoceto, C.; Orsini, F.; De Pascale, S. Plant responses in saline and arid environments: An overview. Eur. J. Plant Sci. Biotechnol. 2011, 5, 1-11. 
7. Pasternak, D.; Aronson, J.A.; Ben-Dov, J.; Forti, M.; Mendlinger, S.; Nerd, A.; Sitton, D. Development of new arid zone crops for the Negev Desert of Israel. J. Arid Environ. 1986, 11, 37-59. [CrossRef]

8. Dag, A.; Tugendhaft, Y.; Yogev, U.; Shatzkin, N. Commercial cultivation of olive (Olea europaea L.) with saline water under extreme desert conditions. In Proceedings of the Fifth International Symposium on Olive Growing, Izmir, Turkey, 27 September 2004; pp. 279-284.

9. Gucci, R.; Tattini, M. Salinity tolerance in olive. Hortic. Rev. 1997, 21, 177-214.

10. Gucci, R.; Caruso, G. Environmental stresses and sustainable olive growing. In Proceedings of the XXVIII International Horticultural Congress on Science and Horticulture for People (IHC2010): Olive Trends Symposium, Lisbon, Portugal, 22 August 2010; pp. 19-30.

11. Fernández, J.E.; Moreno, F.; Cabrera, F.; Arrue, J.L.; Martín-Aranda, J. Drip irrigation, soil characteristics and the root distribution and root activity of olive trees. Plant Soil 1991, 133, 239-251. [CrossRef]

12. Weissbein, S.; Wiesman, Z.; Ephrath, Y.; Silberbush, M. Vegetative and reproductive response of olive cultivars to moderate saline water irrigation. HortScience 2008, 43, 320-327. [CrossRef]

13. Ayers, R.S.; Westcot, D.W. Water Quality for Agriculture. Irrigation and Drainage Paper No. 29; Food and Agriculture Organization of the United Nations: Rome, Italy, 1985.

14. Aragüés, R.; Puy, J.; Royo, A.; Espada, J.L. Three-year field response of young olive trees (Olea europaea L., cv. Arbequina) to soil salinity: Trunk growth and leaf ion accumulation. Plant Soil 2005, 271, 265-273. [CrossRef]

15. Ben-Gal, A. Salinity and olive: From physiological responses to orchard management. Isr. J. Plant Sci. 2011, 59, 15-28. [CrossRef]

16. Weissbein, S. Characterization of New Olive (Olea Europea L.) Varieties Response to Irrigation with Saline Water in the Ramat Negev Area; Ben Gurion University: Beersheba, Israel, 2006.

17. Rewald, B.; Rachmilevitch, S.; Ephrath, J.E. Salt stress effects on root systems of two mature olive cultivars. Acta Hortic. 2011, 888, 109-118. [CrossRef]

18. Hill, A.; Rewald, B.; Rachmilevitch, S. Belowground dynamics in two olive varieties as affected by saline irrigation. Sci. Hortic. 2013, 162, 313-319. [CrossRef]

19. Soda, N.; Ephrath, J.E.; Dag, A.; Beiersdorf, I.; Presnov, E.; Yermiyahu, U.; Ben-Gal, A. Root growth dynamics of olive (Olea europaea L.) affected by irrigation induced salinity. Plant Soil 2017, 411, 305-318. [CrossRef]

20. Wiesman, Z.; Itzhak, D.; Dom, N.B. Optimization of saline water level for sustainable Barnea olive and oil production in desert conditions. Sci. Hortic. 2004, 100, 257-266. [CrossRef]

21. Tal, A. Rethinking the sustainability of Israel's irrigation practices in the Drylands. Water Res. 2016, 90, 387-394. [CrossRef]

22. Keller, J.; Bliesner, R.D. Sprinkle and Trickle Irrigation; Springer: New York, NY, USA, 1990.

23. Metochis, C. Irrigation of 'Koroneiki' olives with saline water. Olivae 1999, 76, 22-24.

24. Melgar, J.C.; Mohamed, Y.; Serrano, N.; García-Galavís, P.A.; Navarro, C.; Parra, M.A.; Benlloch, M.; Fernández-Escobar, R. Long term responses of olive trees to salinity. Agric. Water Manag. 2009, 96, 1105-1113. [CrossRef]

25. Bruins, H.J. Ancient desert agriculture in the Negev and climate-zone boundary changes during average, wet and drought years. J. Arid Environ. 2012, 86, 28-42. [CrossRef]

26. Lamm, F.R.; Bordovsky, J.P.; Schwankl, L.J.; Grabow, G.L.; Enciso-Medina, J.; Peters, R.T.; Colaizzi, P.D.; Trooien, T.P.; Porter, D.O. Subsurface drip irrigation: Status of the technology in 2010. Trans. ASABE 2012, 55, 483-491. [CrossRef]

27. Martínez, J.; Reca, J. Water use efficiency of surface drip irrigation versus an alternative subsurface drip irrigation method. J. Irrig. Drain. Eng. 2014, 140. [CrossRef]

28. Dorta-Santos, M.; Tejedor, M.; Jiménez, C.; Hernández-Moreno, J.M.; Palacios-Díaz, M.P.; Díaz, F.J. Evaluating the sustainability of subsurface drip irrigation using recycled wastewater for a bioenergy crop on abandoned arid agricultural land. Ecol. Eng. 2015, 79, 60-68. [CrossRef]

29. Dorta-Santos, M.; Tejedor, M.; Jiménez, C.; Hernández-Moreno, J.M.; Díaz, F.J. Using marginal quality water for an energy crop in arid regions: Effect of salinity and boron distribution patterns. Agric. Water Manag. 2016, 171, 142-152. [CrossRef]

30. Roberts, T.L.; White, S.A.; Warrick, A.W.; Thompson, T.L. Tape depth and germination method influence patterns of salt accumulation with subsurface drip irrigation. Agric. Water Manag. 2008, 95, 669-677. [CrossRef]

31. Oron, G.; De Malach, Y.; Gillerman, L.; David, I.; Rao, V.P. Improved saline-water use under subsurface drip irrigation. Agric. Water Manag. 1999, 39, 19-33. [CrossRef] 
32. Thompson, T.L.; Pang, H.C.; Li, Y.Y. The potential contribution of subsurface drip irrigation to water-saving agriculture in the western USA. Agric. Sci. China 2009, 8, 850-854.

33. Trifonov, P.; Lazarovitch, N.; Arye, G. Increasing water productivity in arid regions using low-discharge drip irrigation: A case study on potato growth. Irrig. Sci. 2017, 35, 287-295. [CrossRef]

34. Trifonov, P.; Lazarovitch, N.; Arye, G. Water and Nitrogen Productivity of Potato Growth in Desert Areas under Low-Discharge Drip Irrigation. Water 2018, 10, 970. [CrossRef]

35. Mounzer, O.; Pedrero-Salcedo, F.; Nortes, P.A.; Bayona, J.M.; Nicolás-Nicolás, E.; Alarcón, J.J. Transient soil salinity under the combined effect of reclaimed water and regulated deficit drip irrigation of Mandarin trees. Agric. Water Manag. 2013, 120, 23-29. [CrossRef]

36. Oster, J.D.; Shainberg, I. Soil responses to sodicity and salinity: Challenges and opportunities. Soil Res. 2001, 39, 1219-1224. [CrossRef]

37. Levy, G.J.; Fine, P.; Goldstein, D.; Azenkot, A.; Zilberman, A.; Chazan, A.; Grinhut, T. Long term irrigation with treated wastewater (TWW) and soil sodification. Biosyst. Eng. 2014, 128, 4-10. [CrossRef]

38. Bedbabis, S.; Trigui, D.; Ahmed, C.B.; Clodoveo, M.L.; Camposeo, S.; Vivaldi, G.A.; Rouina, B.B. Long-terms effects of irrigation with treated municipal wastewater on soil, yield and olive oil quality. Agric. Water Manag. 2015, 160, 14-21. [CrossRef]

39. Ayoub, S.; Al-Shdiefat, S.; Rawashdeh, H.; Bashabsheh, I. Utilization of reclaimed wastewater for olive irrigation: Effect on soil properties, tree growth, yield and oil content. Agric. Water Manag. 2016, 176, 163-169. [CrossRef]

40. Erel, R.; Eppel, A.; Yermiyahu, U.; Ben-Gal, A.; Levy, G.; Zipori, I.; Schaumann, G.E.; Mayer, E.; Dag, A. Long-term irrigation with reclaimed wastewater: Implications on nutrient management, soil chemistry and olive (Olea europaea L.) performance. Agric. Water Manag. 2019, 213, 324-335. [CrossRef]

41. Bader, B.; Aissaoui, F.; Kmicha, I.; Salem, A.B.; Chehab, H.; Gargouri, K.; Boujnah, D.; Chaieb, M. Effects of salinity stress on water desalination, olive tree (Olea europaea L. cvs 'Picholine','Meski'and 'Ascolana') growth and ion accumulation. Desalination 2015, 364, 46-52. [CrossRef]

42. Ben-Gal, A.; Beiersdorf, I.; Yermiyahu, U.; Soda, N.; Presnov, E.; Zipori, I.; Crisostomo, R.R.; Dag, A. Response of young bearing olive trees to irrigation-induced salinity. Irrig. Sci. 2017, 35, 99-109. [CrossRef]

43. Banin, A.; Amiel, A. A correlative study of the chemical and physical properties of a group of natural soils of Israel. Geoderma 1970, 3, 185-198. [CrossRef]

44. Rhoades, J.D. Cation exchange capacity. In Agronomy Monograph No. 9 Methods of Soil Analysis: Part 2. Chemical and Microbiological Properties, 2nd ed.; Page, A.L., Miller, R.H., Kearney, D.R., Eds.; ASA, SSSA: Madison, WI, USA, 1986; pp. 149-157.

45. Thomas, G.W. Exchangeable cations. In Agronomy Monograph No 9 Methods of Soil Analysis. Part 2. Chemical and Microbiological Properties, 2nd ed.; Page, A.L., Miller, R.H., Keerney, D.R., Eds.; ASA, SSSA: Madison, WI, USA, 1986; pp. 159-164.

46. Fares, A.; Parsons, L.R.; Wheaton, T.A.; Morgan, K.T.; Simunek, J.; Van Genuchten, M.T. Simulated drip irrigation with different soil types. Proc. Fla. State Hortic. Soc. 2001, 114, 22-24.

47. Sevostianova, E.; Leinauer, B.; Sallenave, R.; Karcher, D.; Maier, B. Soil salinity and quality of sprinkler and drip irrigated warm-season turfgrasses. Agron. J. 2011, 103, 1773-1784. [CrossRef]

48. Ben-Hur, M.; Li, F.H.; Keren, R.; Ravina, I.; Shalit, G. Water and salt distribution in a field irrigated with marginal water under high water table conditions. Soil Sci. Soc. Am. J. 2001, 65, 191-198. [CrossRef]

49. Lado, M.; Bar-Tal, A.; Azenkot, A.; Assouline, S.; Ravina, I.; Erner, Y.; Fine, P.; Dasberg, S.; Ben-Hur, M. Changes in chemical properties of semiarid soils under long-term secondary treated wastewater irrigation. Soil Sci. Soc. Am. J. 2012, 76, 1358-1369. [CrossRef]

50. Levy, R.; Hillel, D. Thermodynamic Equilibrium Constants of Sodium-Calcium Exchange in Some Israel SOILS1. Soil Sci. 1968, 106, 393-398. [CrossRef]

51. United States Department of Agriculture. Diagnosis and improvement of saline and alkali soils. In Agriculture Handbook; US Government Printing Office: Washington, DC, USA, 1954; Volume 60, pp. 83-100.

(C) 2019 by the authors. Licensee MDPI, Basel, Switzerland. This article is an open access article distributed under the terms and conditions of the Creative Commons Attribution (CC BY) license (http://creativecommons.org/licenses/by/4.0/). 